\title{
MANUSIA DALAM AL-QUR'AN
}

\author{
Muhammad Dawam Saleh \\ Sekolah Tinggi Ilmu Al-Qur'an dan Sains Al-Ishlah (STIQSI) \\ Sendangagung Paciran Lamongan \\ Email: dawamsholeh@gmail.com
}

\begin{abstract}
Abstrak
Konsep manusia dalam Al-Qur'an dijelaskan sangat komprehensif, mulai dari proses penciptaan, perjanjian manusia dengan penciptanya, kelahiran, tanggungjawab serta kewajiban yang harus dilakukannya. Manusia sebagai makhluk diberi dua pilihan oleh penciptanya, untuk mengikuti kebajikan atau kejahatan. Manusia selamat karena mengikuti kebajikan, dan sebaliknya. Salah satu kebajikan paling utama adalah shalat, sedangkan kejahatan paling dahsyat adalah kesombongan dan kelalaian dalam shalat. Tulisan ini mengurai, menganalisis dan mendeskripsikan secara lengkap dan kritis menggunakan pendekatan linguistik dan semantik, bagaimana konsep manusia dalam Al-Qur'an.
\end{abstract}

Kata Kuci : Manusia, Insan, Nas, Basyar

\section{Pendahuluan}

Manusia dalam al-Qur'an disebut dengan beberapa nama, di antaranya dengan sebutan al-insu (الإنس) sebanyak 17 kali, dengan kata al-insan (الإنسان) sebanyak 64 kali, dan bentuk jamaknya yaitu unas (أناس) sebanyak 5 kali, dan annas (الناس) sebanyak 114 kali. Kata "manusia” juga menjadi nama surat, satu surat al-Insan (الإنسان) dan satu lagi surat an-Nas (الناس). Selain itu, manusia juga disebut di dalam Al-Qur'an dengan kata al-basyar (البشر) sebanyak 37 kali, al-mala' (الملأ) sebanyak 17 kali, al-anam (الأنام) sebanyak 1 kali, al-bariyah (البرية) sebanyak 2 kali, dan bani Adam (بنى آدم) sebanyak 3 kali.

Al-Qur'am al-Karim, di samping membicarakan tentang keesaan Allah dalam sifat, asma dan af'al-Nya, tentang Hari Akhir, malaikat-malaikat, kitab-kitab Allah, dan alam semesta, yang paling banyak dibicarakan dalam kitab suci ini justru manusia, baik sebagai subjek maupun objek (mukhotob). Tujuan utama diturunkannya al-Qur'an adalah untuk manusia melalui utusannya yakni Nabi Muhammad Saw. 


\section{Penciptaan Manusia}

1. Penciptaan Adam As tidak seperti penciptaan manusia pada umumnya. Adam diciptakan dari turab (tanah), tidak melalui nutfah (air mani). Penciptaan Siti Hawa juga khas karena diambil dari tulang rusuk kiri Adam. Penciptaan Nabi Isa As juga unik karena lahir dari rahim seorang ibu (Maryam) tapi tanpa seorang ayah. Penciptaan Isa As ini memiliki kemiripan dengan Adam As, yakni samasama diciptakan dari turab sebagaimana disebut dalam surat an-Nisa ayat 1 , dan ali-Imran ayat 59.

2. Penciptaan anak-cucu Adam (Bani Adam) selebihnya terjadi melalui proses kejadian yang bertahap. Al-Qur'an menyebut bahwa seluruh manusia diciptakaan dari turab (tanah atau debu) -disebut dalam Al-Qur'an sebanyak 6 kali- atau dari thin (lumpur, tanah, pasir, dan lumpur dicampur pasir) -disebut dalam Al-Qur'an sebanyak 8 kali.

Dari tahap turab atau thin ini, bakal manusia kemudian dijadikan nutfah atau air mani yang ditempatkan di dalam tempat yang kokoh, yakni rahim wanita. Kemudian berkembang menjadi 'alaqah (segumpal darah), lalu menjadi mudghah (segumpal daging), kemudian bekembang menjadi tulang-tulang yang dilapisi daging dan kulit, lalu jadilah manusia (al-Hajj: 5 dan al-Mu'minun: 14).

Sementara itu hadits Rasulullah Saw yang diriwayatkan oleh Bukhari dan Muslim menyatakan bahwa manusia diciptakan dalam perut ibunya selama 40 hari berupa nutfah (mani), kemudian 40 hari lagi menjadi alaqah (segumpal darah), kemudian 40 hari lagi menjadi mudghah (segumpal daging). Kemudian malaikat diutus oleh Allah Swt untuk memberikan roh padanya dan diperintahkan untuk menulis empat hal, yaitu: rezekinya, waktu matinya, pekerjaannya, dan apakah dia sengsara atau bahagia.

\section{Keutamaan Manusia}

1. Keutamaan bentuk

Disebutkan dalam surat at-Thin ayat 4 bahwa manusia diciptakan dengan

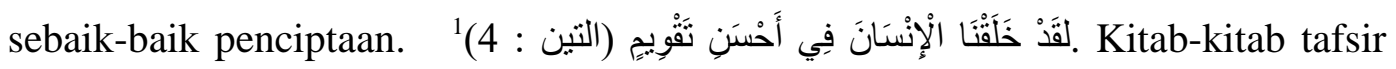

\footnotetext{
${ }^{1}$ QS. At-Thin (95): 4.
} 


\section{Muhammad Dawam Saleh}

menyebutkan bahwa taqwim di sini dimaknai sebagai bentuk, gambar, postur, anggota-anggota tubuh yang terbaik.

Dalam surat Ghafir ayat 64 dan surat at-Taghobun ayat 3 juga disebutkan bahwa Allah telah memperindah bentuk rupa atau gambar manusia فأحسَنَ صُوَرَكُمَ

\section{Keutamaan kemampuan}

Nabi Adam lebih unggul dibanding malaikat dalam hal pengetahuan karena Adam diberi ilmu yang tidak diberikan kepada malaikat. Hal itu terjadi ketika Allah Swt memberitahukan kepada para malaikat tentang rencana menciptakan manusia yang akan menjadi khalifah di bumi. Namun malaikat mempertanyakan rencana itu dengan menyebut bahwa mahluk yang akan diciptakannya itu memiliki tabiat buruk suka membunuh dan menumpahkan darah. Lalu Allah SWT ingin menunjukkan keunggulan manusia kepada malaikat. Maka diajarilah Adam nama-nama yang tidak diajarkan kepada malaikat. Ketika para malaikat ditanya tentang nama-nama itu, tentu mereka tidak tahu. Lalu Allah Swt memerintahkan Adam untuk memberitahu malaikat tentang nama-nama tersebut. Di sinilah Allah menunjukkan keunggulan manusia atas malaikat. Kisah ini disebutkan dalam surat al-Baqarah ayat 34, al-A'raf ayat 11, al-Isra ayat 61, al-Kahfi ayat 40, dan Thaha ayat 116 .

\section{Kesempurnaan roh dan jasad}

Manusia terdiri dari roh dan jasad. Roh (jiwa) manusia berupa cipta (akal, ilmu pengetahuan), rasa (duka, gembira, bangga, pesimis, indah, dsb.), karsa (kehendak baik dan buruk). Kemampuan cipta, rasa dan karsa itu bisa diciptakan oleh manusia dalam bentuk-bentuk lahiriyah, jasadiyah, hissiyah karena manusia mempunyai bentuk tubuh yang paling baik (ahsani taqwim). Dengan demikian lahirlah kreasi-kreasi hasil budidaya manusia mulai dari tempat tinggal hingga kendaraan dan aneka teknologi. Hal ini tidak kita jumpai pada malaikat. Adapun jin juga kita dengar adanya peramaan kemampuan-kemampuan tertentu seperti manusia, tapi tidak nampak dalam wujud konkret sebagaimana yang kita dapati pada hasil karya manusia. 


\section{Kelemahan-Kelemahan Manusia dan Solusinya}

1. Manusia itu lemah

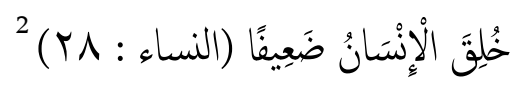

Artinya: manusia dijadikan bersifat lemah.

Solusinya adalah dengan bertaubat dan menjaga syahwat, seperti yang disebutkan dalam al-Qur'an surat an-Nisa' ayat 27:

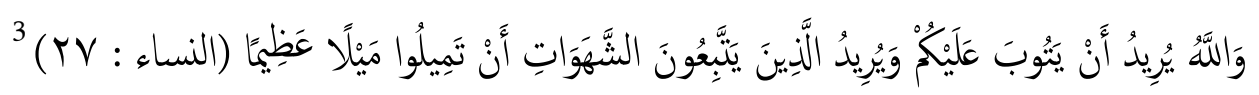

Artinya: Dan Allah hendak menerima taubatmu, sedang orang-orang yang mengikuti hawa nafsunya bermaksud supaya kamu berpaling sejauh-jauhnya (dari kebenaran).

2. Manusia itu tergesa-gesa

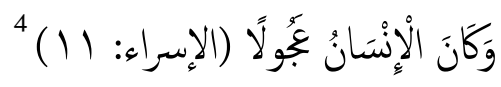

Artinya : Dan memang manusia bersifat tergesa-gesa.

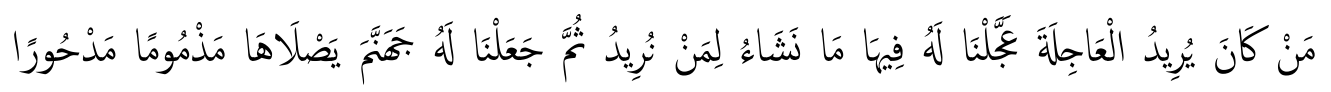

$$
5(\mid 1: \text { : الإسراء) }
$$

Artinya: Barangsiapa menghendaki kehidupan sekarang (duniawi), maka Kami segerakan baginya di dunia itu apa yang Kami kehendaki bagi orang yang Kami kehendaki dan Kami tentukan baginya neraka jahannam; ia akan memasukinya dalam keadaan tercela dan terusir.

3. Manusia itu kufur

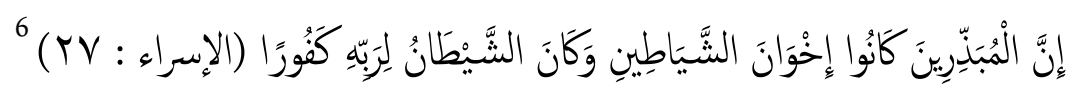

Artinya: Sesungguhnya pemboros-pemboros itu adalah saudara-saudara syaitan dan syaitan itu adalah sangat ingkar kepada Tuhannya.

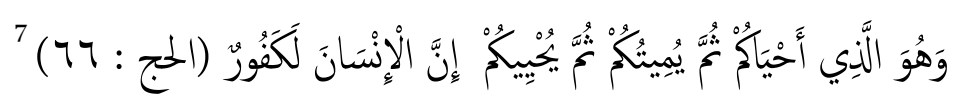

\footnotetext{
${ }^{2}$ QS. An Nisa (4): 28.

${ }^{3}$ Ibid, 27.

${ }^{4}$ QS. Al Isra' (17): 11.

${ }^{5}$ QS. Al Isra' (17): 18.

${ }^{6}$ Ibid, 27.
} 


\section{Muhammad Dawam Saleh}

Artinya: Dan Dialah Allah yang telah menghidupkan kamu, kemudian mematikan kamu, kemudian menghidupkan kamu (lagi), sesungguhnya manusia itu, benar-benar sangat mengingkari nikmat.

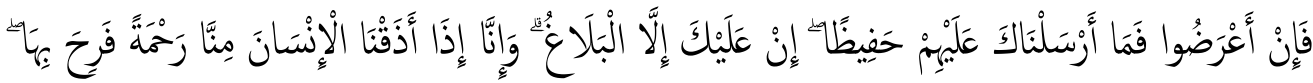

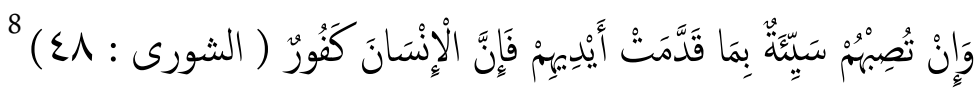

Artinya: Jika mereka berpaling maka Kami tidak mengutus kamu sebagai pengawas bagi mereka. Kewajibanmu tidak lain hanyalah menyampaikan (risalah). Sesungguhnya apabila Kami merasakan kepada manusia sesuatu rahmat dari Kami dia bergembira ria karena rahmat itu. Dan jika mereka ditimpa kesusahan disebabkan perbuatan tangan mereka sendiri (niscaya mereka ingkar) karena sesungguhnya manusia itu amat ingkar (kepada nikmat).

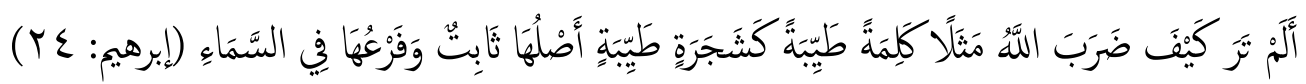

Artinya: Tidakkah kamu perhatikan bagaimana Allah telah membuat perumpamaan kalimat yang baik seperti pohon yang baik, akarnya teguh dan cabangnya (menjulang) ke langit.

$$
9
$$

Artinya: Apabila ia ditimpa kesusahan ia berkeluh kesah

4. Manusia bakhil

$$
\text { وَكَانَ الْإِنْسَانُ قَتَورًا (الإسراء : . }
$$

Artinya: Dan adalah manusia itu sangat kikir.

Solusinya adalah menyadari segalanya itu milik Allah seperti yang disebutkan dalam surat al-Isra' ayat 55 .

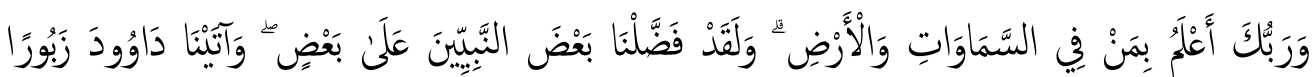

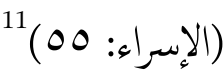

\footnotetext{
${ }^{7}$ QS. Al Hajj (22): 66.

${ }^{8}$ QS. Asy Syura (42): 48.

${ }^{9}$ QS. Al Ma'arij (70): 20.

${ }^{10}$ QS. Al Isra' (17): 100.

${ }^{11} \mathrm{Ibid}, 55$.
} 
Artinya: Dan Tuhan-mu lebih mengetahui siapa yang (ada) di langit dan di bumi. Dan sesungguhnya telah Kami lebihkan sebagian nabi-nabi itu atas sebagian (yang lain), dan Kami berikan Zabur kepada Daud.

5. Manusia itu mudah sedih, berkeluh kesah dan kikir

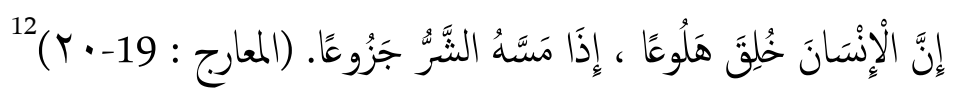

Artinya: Sesungguhnya manusia diciptakan bersifat keluh kesah lagi kikir. Apabila ia ditimpa kesusahan ia berkeluh kesah.

Penyelesaiannya adalah sholat terus menerus, suka bersedekah, mempercayai hari pembalasan, menjaga kemaluan dan memelihara amanah, seperti yang disebutkan di dalam Al-Qur'an surat al-Ma'arij ayat 22-34.

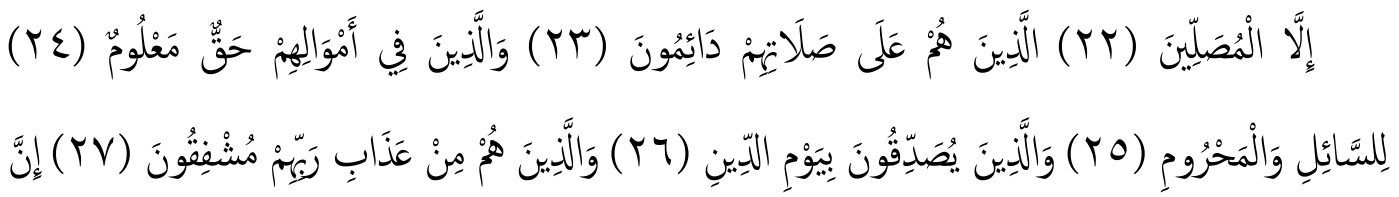

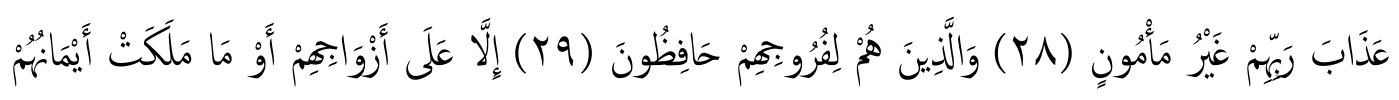

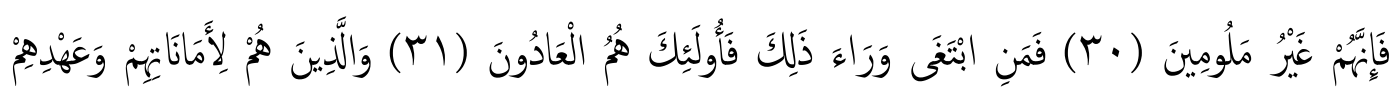

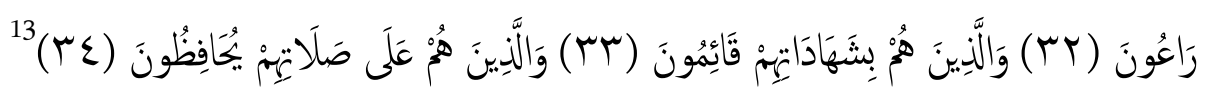

Artinya: kecuali orang-orang yang mengerjakan salat, yang mereka itu tetap mengerjakan salatnya; dan orang-orang yang dalam hartanya tersedia bagian tertentu, bagi orang (miskin) yang meminta dan orang yang tidak mempunyai apa-apa (yang tidak mau meminta); dan orang-orang yang mempercayai hari pembalasan, dan orang-orang yang takut terhadap azab Tuhannya, karena sesungguhnya azab Tuhan mereka tidak dapat orang merasa aman (dari kedatangannya); Dan orang-orang yang memelihara kemaluannya, kecuali terhadap istri-istri mereka atau budak-budak yang mereka miliki, maka sesungguhnya mereka dalam hal ini tidak tercela. Barang siapa mencari yang di balik itu maka mereka itulah orang-orang yang melampaui batas; Dan orangorang yang memelihara amanat-amanat (yang dipikulnya) dan janjinya. Dan

\footnotetext{
${ }^{12}$ QS. Al Ma'arij (70): 19-20.

${ }^{13} \mathrm{Ibid}, 22-34$.
} 


\section{Muhammad Dawam Saleh}

orang-orang yang memberikan kesaksiannya. Dan orang-orang yang memelihara salatnya.

6. Manusia itu suka membantah

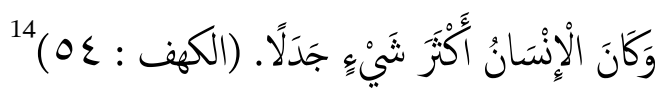

Artinya: Dan manusia adalah makhluk yang paling banyak membantah.

Solusinya adalah dengan mengimani ayat-ayat dan perumpamaanperumpamaan Allah Swt, seperti yang disebutkan dalam Al-Qur'an surat al-Kahfi ayat 55 .

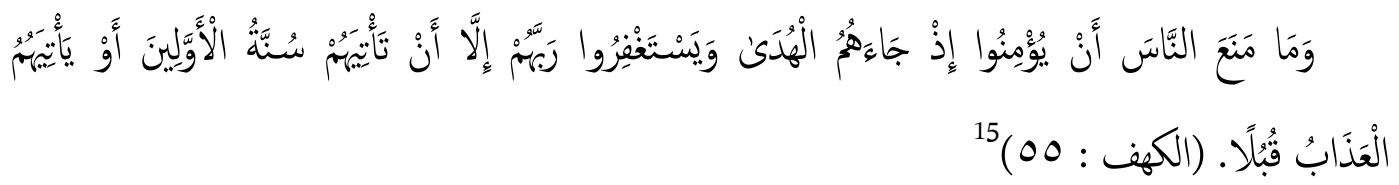

Artinya: Dan tidak ada sesuatupun yang menghalangi manusia dari beriman, ketika petunjuk telah datang kepada mereka, dan dari memohon ampun kepada Tuhannya, kecuali (keinginan menanti) datangnya hukum (Allah yang telah berlalu pada) umat-umat yang dahulu atau datangnya azab atas mereka dengan nyata.

7. Manusia itu mudah rakus harta, tahta dan wanita.

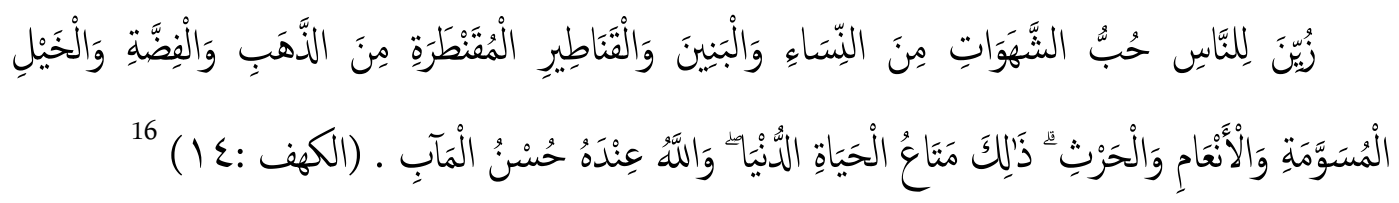

Artinya: Dijadikan indah pada (pandangan) manusia kecintaan kepada apaapa yang diingini, yaitu: wanita-wanita, anak-anak, harta yang banyak dari jenis emas, perak, kuda pilihan, binatang-binatang ternak dan sawah ladang. Itulah kesenangan hidup di dunia, dan di sisi Allah-lah tempat kembali yang baik (surga).

Solusinya adalah menjadi orang yang bertaqwa, seperti yang disebutkan dalam Al-Qur'an surat al-Kahfi ayat 15.

\footnotetext{
${ }^{14}$ QS. Al Kahfi (18): 54.

${ }^{15} \mathrm{Ibid}, 55$.

${ }^{16} \mathrm{Ibid}, 14$.
} 


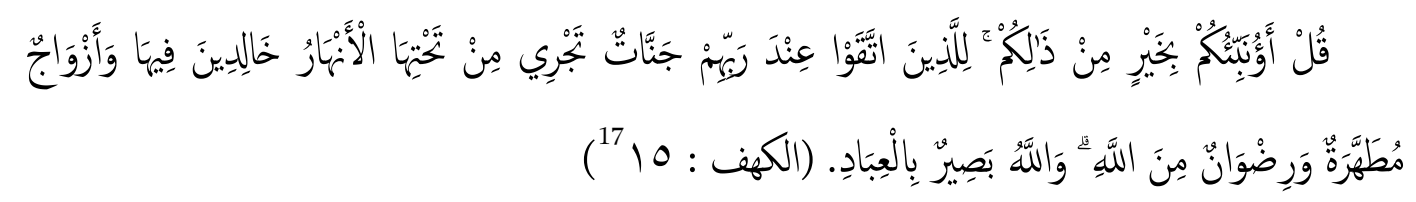

Artinya: Katakanlah: "Inginkah aku kabarkan kepadamu apa yang lebih baik dari yang demikian itu?". Untuk orang-orang yang bertakwa (kepada Allah), pada sisi Tuhan mereka ada surga yang mengalir dibawahnya sungai-sungai; mereka kekal didalamnya.Dan (mereka dikaruniai) isteri-isteri yang disucikan serta keridhaan Allah. Dan Allah Maha Melihat akan hamba-hamba-Nya.

8. Manusia itu dzalim dan bodoh

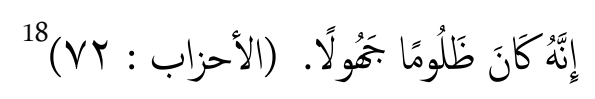

Artinya: Sesungguhnya manusia itu amat zalim dan amat bodoh

Solusinya adalah menjadi orang yang beriman dengan tidak menjadi munafiq lagi musyrik, seperti yang disebutkan dalam Al-Qur'an surat al-Ahzab ayat 73.

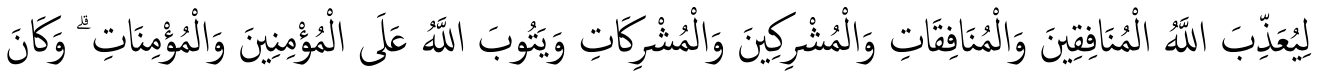

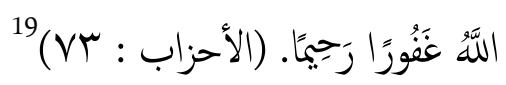

Artinya: sehingga Allah mengazab orang-orang munafik laki-laki dan perempuan dan orang-orang musyrikin laki-laki dan perempuan; dan sehingga Allah menerima taubat orang-orang mukmin laki-laki dan perempuan. Dan adalah Allah Maha Pengampun lagi Maha Penyayang.

Seluruh kekurangan dan kelemahan manusia itu bisa diatasi dengan menjadi orang yang menang, sejahtera, bahagia lahir batin demi akhirat dengan melaksanakan rukun-rukun Iman dan Islam serta ber-ihsan yang menyatus pada istilah "bertaqwa". Hal ini bisa kita lihat pada surat al-Mu'minun ayat 1-11 dan surat ath-Tholaq ayat 2-5.

Sebagai contoh adalah surat al-Mu'minun ayat 1-11:

\footnotetext{
${ }^{17}$ Ibid, 15

${ }^{18}$ QS. Al Ahzab (33):72.

${ }^{19}$ QS. Al Ahzab (73): 1-11.
} 


\section{Muhammad Dawam Saleh}

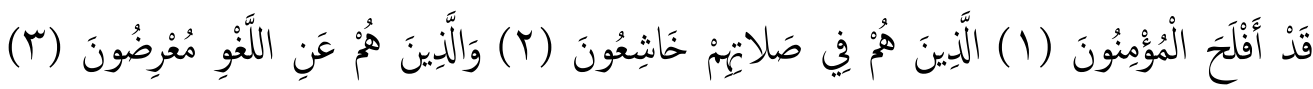

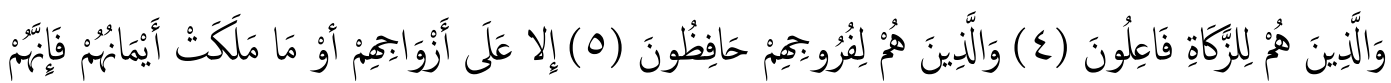

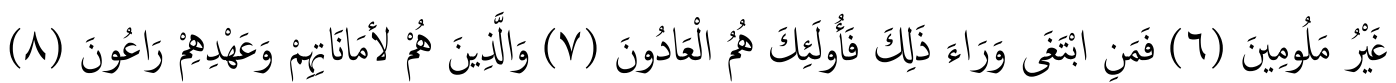

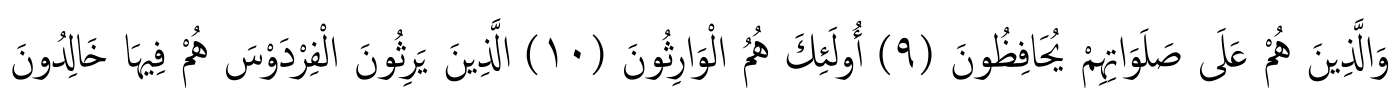
${ }^{20}(11-1$ : (المؤمنون (1) (1)

Artinya: Sesungguhnya beruntunglah orang-orang yang beriman, yaitu orang-orang yang khusyu' dalam sholatnya, dan orang-orang yang menjauhkan diri dari (perkataan dan perbuatan) yang tiada berguna, dan orang-orang yang menunaikan zakat, dan orang-orang yang menjaga kemaluannya, kecuali terhadap isteri-isteri mereka atau budak yang mereka miliki maka sesungguhnya mereka dalam hal ini tiada tercela, barang siapa yang mencari di balik itu maka mereka itulah yang orang-orang melampui batas; dan orang-orang yang memelihara amanat (yang dipikulnya) dan janjinya; dan orang-orang yang memelihara sholatnya. Mereka itulah yang akan mewarisi, yakni yang akan mewarisi surga Firdaus, mereka kekal di dalamnya.

Disebutkan bahwa orang-orang beriman akan beruntung, sukses dan sejahtera apabila mereka khusyu' dalam sholat, meninggalkan perbuatan-perbuatan yang tidak berguna, yang mengeluarkan zakat atau shodaqah, tidak berzina, menjaga amanah, menepati janji dan menjaga sholat. Dalam surat ath-Thalaq ayat 2-5 disebutkan:

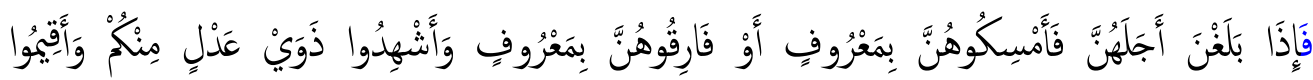

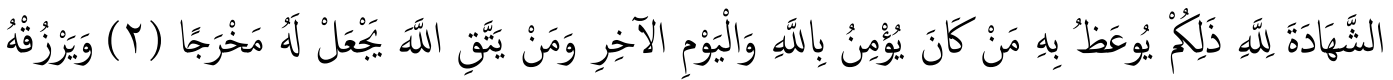

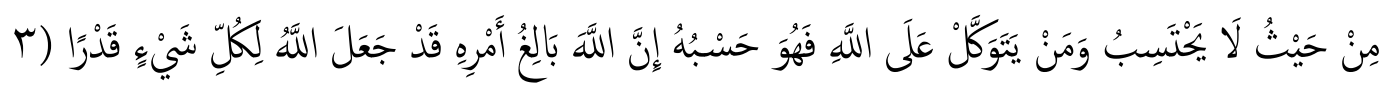

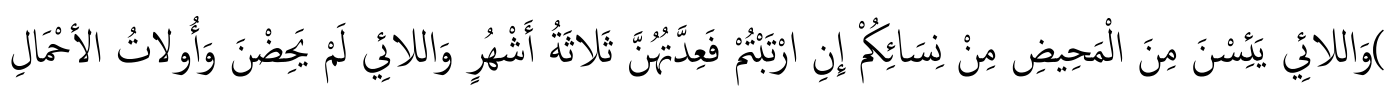

${ }^{20}$ QS. Al Mu'minun (23): 1-11. 


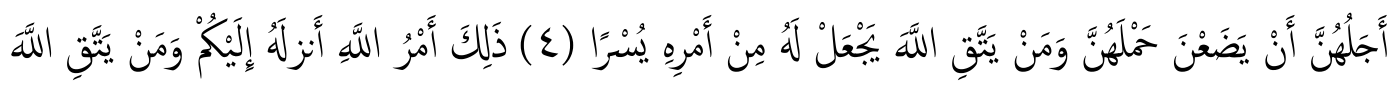

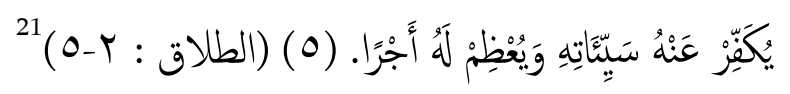

Artinya: Apabila mereka telah mendekati akhir iddahnya, maka rujukilah mereka dengan baik atau lepaskanlah mereka dengan baik, dan persaksikanlah dengan dua orang saksi yang adil di antara kamu, dan hendaklah kamu tegakkan kesaksian itu karena Allah. Demikianlah diberi pengajaran dengan itu orang yang beriman kepada Allah dan Hari Akhirat. Barangsiapa bertakwa kepada Allah niscaya Dia akan mengadakan baginya jalan keluar. Dan memberinya rezeki dari arah yang tiada disangka-sangkanya, dan barangsiapa yang bertawakkal kepada Allah niscaya Allah akan mencukupkan (keperluan)nya. Sesungguhnya Allah melaksanakan urusan yang (dikehendaki)Nya. Sesungguhnya Allah telah mengadakan ketentuan bagi tiap-tiap sesuatu. Dan perempuanperempuan yang tidak haid lagi (monopause) di antara perempuan-perempuanти jika kamu ragu-ragu (tentang masa iddahnya), maka masa iddah mereka adalah tiga bulan; dan begitu (pula) perempuan-perempuan yang tidak haid. Dan perempuan-perempuan yang hamil, waktu iddah mereka ialah sampai mereka melahirkan kandungannya. Dan barangsiapa bertakwa kepada Allah, niscaya Allah menjadikan baginya kemudahan dalam urusannya. Itulah perintah Allah yang diturunkan-Nya kepada kamu, dan barangsiapa bertakwa kepada Allah, niscaya Dia akan menghapus kesalahan-kesalahannya dan melipatgandakan pahala baginya.

Dalam surat at-Tholaq ayat 2-5 tersebut ditegaskan: "Barangsiapa yang bertaqwa maka Allah akan menjadikan jalan keluar baginya. Allah akan memberinya rezeki dari angka yang tak disangka-sangka, Allah akan memudahkan urusannya, Allah akan menghapus keburukan-keburukannya dan melipat gandakan pahala baginya".

${ }^{21}$ QS. At Thalaq (65): 2-5. 
Muhammad Dawam Saleh

\section{Daftar Pustaka}

Al-Qur'an Al-Karim

Al-Qur'an dan Terjemahannya, Khadim al-Haramayn, 1418 H. 